\title{
1,6-Interactions between dimethylamino and aldehyde groups in two biphenyl derivatives
}

\author{
Jane O'Leary, John D. Wallis and Michael L. Wood
}

Acta Cryst. (2001). C57, 851-853

Copyright (C) International Union of Crystallography

Author(s) of this paper may load this reprint on their own web site or institutional repository provided that this cover page is retained. Republication of this article or its storage in electronic databases other than as specified above is not permitted without prior permission in writing from the IUCr.

For further information see http://journals.iucr.org/services/authorrights.html

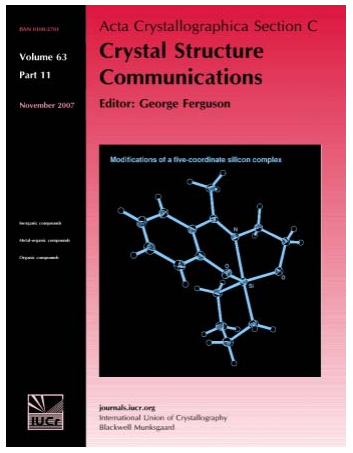

Acta Crystallographica Section C: Crystal Structure Communications specializes in the rapid dissemination of high-quality studies of crystal and molecular structures of interest in fields such as chemistry, biochemistry, mineralogy, pharmacology, physics and materials science. The numerical and text descriptions of each structure are submitted to the journal electronically as a Crystallographic Information File (CIF) and are checked and typeset automatically prior to peer review. The journal is well known for its high standards of structural reliability and presentation. Section $C$ publishes approximately 1000 structures per year; readers have access to an archive that includes high-quality structural data for over 10000 compounds.

Crystallography Journals Online is available from journals.iucr.org 
Acta Crystallographica Section C

\section{Crystal Structure}

Communications

ISSN 0108-2701

\section{1,6-Interactions between dimethyl- amino and aldehyde groups in two biphenyl derivatives}

\author{
Jane O'Leary, John D. Wallis* and Michael L. Wood \\ Department of Chemistry and Physics, The Nottingham Trent University, Clifton \\ Lane, Nottingham NG11 8NS, England \\ Correspondence e-mail: john.wallis@ntu.ac.uk
}

Received 8 March 2001

Accepted 17 April 2001

The title compounds, 2-(dimethylamino)biphenyl-2'-carboxaldehyde, $\mathrm{C}_{15} \mathrm{H}_{15} \mathrm{NO}$, and 2-(dimethylamino)biphenyl-2',6'dicarboxaldehyde, $\mathrm{C}_{16} \mathrm{H}_{15} \mathrm{NO}_{2}$, show similar 1,6-interactions [N... C $=\mathrm{O} 2.929$ (3) to 3.029 (3) $\AA$ ] between the dimethylamino and aldehyde groups located in the ortho positions of the two rings, which lie at 58.1 (1)-62.4 (1) ${ }^{\circ}$ to each other.

\section{Comment}

Interactions between amino and carbonyl groups in natural products such as (I) and (II) have been interpreted as representing different stages in the progress of the corresponding chemical reaction (Bürgi et al., 1973a). Decreasing N..C distances are accompanied by increasing $\mathrm{C}=\mathrm{O}$ bond lengths. 1,5-N...C interactions between dimethylamino groups and various carbonyl-containing functional groups have been observed in peri-naphthalene systems (Schweizer et al., 1978; Clayden et al., 1999; Hodgson et al., 1999), though the shortest N...C distance observed is only 2.489 (5) $\AA$, for interaction with an aldehyde group in (III). Nevertheless, shorter 1,5interactions are observed when the electrophilic group is an

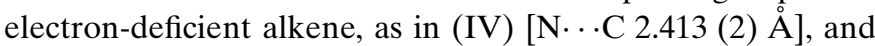
almost complete bond formation is observed in $(\mathrm{V})[\mathrm{N}-\mathrm{C}$ 1.651 (3) A] (Bell \& Wallis, 1999). The use of the N.CC distances in such systems as an indicator of the through-space electron-attracting powers of the electrophilic groups has been proposed (O'Leary et al., 2001). In the naphthalene system, the peri groups are constrained to some degree by the bonding geometry of the ring system. We now report the structures of the biphenyls (VI) and (VII), which contain ortho-dimethylamino and ortho-aldehyde substituents on opposite rings such that they are capable of forming 1,6-N … interactions, but are not compelled by the molecular framework to be near one another at all. The biphenyls were prepared by Suzuki and Stille coupling methodologies and their molecular structures were analysed by single-crystal X-ray diffraction at $150 \mathrm{~K}$.

The results of the crystal structure determinations are shown in Fig. 1, and relevant molecular geometries are summarized in Table 1. Biphenyl (VII) contains two inde- pendent molecules in the asymmetric unit. The three molecular conformations of (VI) and (VII) are very similar. The phenyl rings lie at $58.1(1)-62.4(1)^{\circ}$ to each other such that there is a close $\mathrm{N}$... C contact between the amino $\mathrm{N}$ atom and a carbonyl $\mathrm{C}$ atom. The dimethylamino group adopts pyramidal geometry, with a $\mathrm{N}-\mathrm{CH}_{3}$ bond making a torsion angle

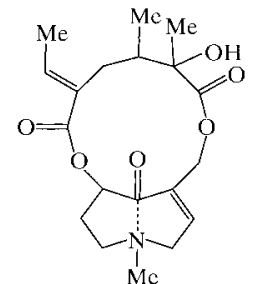

(I)

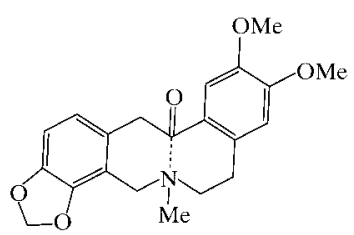

(II)

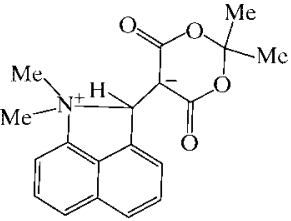

( $)$

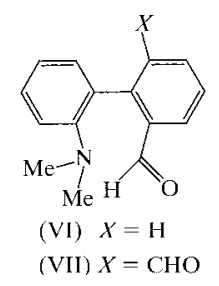

of $13.2(3)-15.0(3)^{\circ}$ to the $\mathrm{C} 2-\mathrm{C} 3$ bond of the phenyl ring and directed away from the second phenyl ring. The carbonyl group lies almost in its phenyl-ring plane, with the carbonyl bond directed away from the second phenyl ring. The $\mathrm{N} \cdots \mathrm{C}$ contact distances, 2.929 (3)-3.029 (3) A, are longer than in the related naphthalene, (III). The $\mathrm{N} \cdots \mathrm{C}=\mathrm{O}$ angles lie in the range $123.8(2)-128.2(2)^{\circ}$, and the theoretical directions of the amino $\mathrm{N}$ atom lone pairs lie $c a 19-25^{\circ}$ to the $\mathrm{N} \cdots \mathrm{C}(=\mathrm{O})$ vectors. The dimethylamino $\mathrm{N}$ atom in (VI) is displaced out of the best plane through its phenyl ring by 0.042 (2) $\AA$ towards the carbonyl group, and the carbonyl $\mathrm{C}$ atom is displaced out of its phenyl-ring plane by $0.066 \AA$ away from the dimethylamino group. In the two conformations of (VII), the out-ofplane displacements of the corresponding aldehyde $\mathrm{C}$ atoms are similar to those in (VI), with values of 0.071 and $0.064 \AA$, respectively, but the dimethylamino $\mathrm{N}$ atoms are not displaced significantly out of the planes of their phenyl groups. Indeed, the $\mathrm{Me}_{2} \mathrm{~N}-\mathrm{C}$ bond lengths of 1.402 (3) and 1.410 (3) $\AA$ are slightly shorter than in (VI), 1.422 (2) А. These two effects might be ascribable to the through-bond electron-attracting power of the second carbonyl group, though there are no other significant bond-length changes in the molecular skeletons. The second aldehyde group in (VII) has little effect on the molecular conformation, making only a van der Waals contact with atom $\mathrm{H} 6$ on the opposite phenyl ring, with C16 - H6 distances of 2.86 (2) and 2.99 (2) $\AA$. There are no particularly short intermolecular interactions in the two crystal structures. In (VI), centrosymmetric C-H. . O interactions with graph-set $R_{2}^{2}(10)$ are present [C9..O $1^{1}$ 
3.4818 (15) $\AA$ and $\mathrm{C}-\mathrm{H} \cdots \mathrm{O}^{\mathrm{i}} 164.8(12)^{\circ}$; symmetry code: (i) $1-x,-y,-z]$ and in (VII), chains form comprising $\mathrm{C}_{A / B} \cdots \mathrm{O} 2_{A / B}^{\mathrm{ii}}$ distances of 3.253 (3) and 3.336 (3) $\AA$, with $\mathrm{C}-\mathrm{H} \cdots \mathrm{O}^{\mathrm{ii}}$ angles of $129(2)$ and $159(3)^{\circ}$, respectively [symmetry code: (ii) $\frac{1}{2}+x,-y, z$ (for $A$ ) and $-\frac{1}{2}+x, 1-y, z$ (for $B$ )].

The observed $\mathrm{Me}_{2} \mathrm{~N} \cdots \mathrm{C}=\mathrm{O}$ interactions are of similar lengths to the $1,5-\mathrm{Me}_{2} \mathrm{~N} /$ ketone carbonyl interactions in methadone of 2.911 and $2.912 \AA$ (Bürgi et al., 1973b; Bye, 1974), where the two groups are not forced to be near one another as they are in the peri-naphthalene series. However, when the ${ }^{13} \mathrm{C}$ NMR spectrum of (VI) was measured in $\mathrm{DCl} / \mathrm{D}_{2} \mathrm{O}$, the appearance of a new resonance at $\delta 90.2$ indicated addition of the dimethylamino group to a protonated

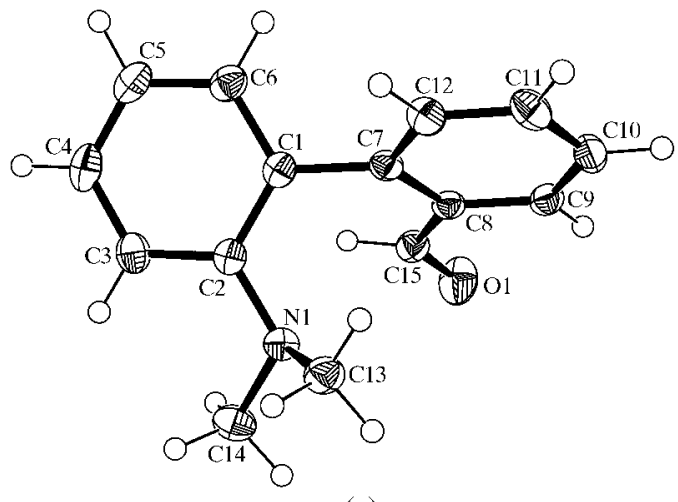

(a)

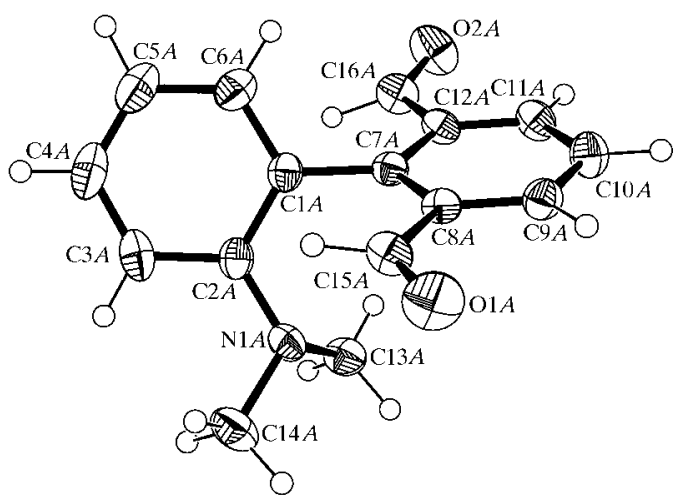

(b)

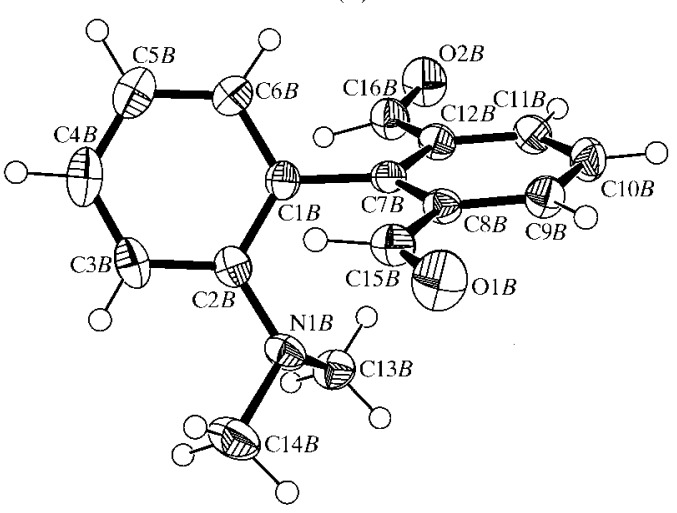

(c)

Figure 1

ORTEPIII (Johnson \& Burnett, 1996) drawings of (a) compound (VI) and $(b)$ and $(c)$ the two molecules of compound (VII), with anisotropic displacement parameters drawn at the $50 \%$ probability level. carbonyl group. There are no directly comparable biphenyl structures with 1,6-amino/carbonyl interactions in the Cambridge Structural Database (CSD; Allen \& Kennard, 1993). The two molecules of 2,2'-bis(dimethylamino)biphenyl (Staab et al., 1988) adopt conformations with the phenyl rings at 56.1 and $59.0^{\circ}$ such that the pyramidal dimethylamino groups are on opposite sides of the molecule. 2-Methoxybiphenyl-2'-carboxylic acid (Krygowski et al., 1989) adopts a conformation with the phenyl rings at $54.4(1)^{\circ}$ such that the methoxy O atom lies 3.023 (5) $\AA$ from the carboxyl C atom. The methoxy group lies close to the best plane of the phenyl ring, so that the unconjugated lone pair is not well aligned with the $\mathrm{MeO} \cdots \mathrm{C}=\mathrm{O}$ vector. Studies in the naphthalene series have shown that $1,5-\mathrm{MeO} \cdots \mathrm{Csp} p^{2}$ interaction distances are remarkably insensitive to the nature of the carbon-containing functional group. In general, biphenyls with one ortho substituent per phenyl ring tend to have their phenyl rings close to perpendicular. Exceptions occur when the substituents are small, as for fluoride or alkoxy, e.g. CSD refcode BAWPUK (Jones \& Brown, 1982), DECFDP (Neronova, 1968), and NOZZOR and NOZZUX (Ferreira et al., 1998), or can hydrogen bond, as in diols, e.g. JUPTOD (Sartori et al., 1992), NUTSUQ (Byrne et al., 1998), a hydroxy ether JAVHIX (Lin et al., 1989) and the 2,2'-diamine DABIPH (Ottersen, 1977), where interplanar angles are $c a 40-55^{\circ}$. The structures of (VI) and (VII) are likely to be more reasonable models for intermolecular interactions between dialkyamino groups and aldehydes than the structure of the related naphthalene derivative (III).

\section{Experimental}

2-(N,N-Dimethylamino)biphenyl-2'-carboxaldehyde, (VI): sodium carbonate $(6.42 \mathrm{~g}, 60.6 \mathrm{mmol})$ dissolved in degassed water $(30 \mathrm{ml})$ was added to a mixture of 2-( $N, N$-dimethylamino)phenylboronic acid $(1.80 \mathrm{~g}), \mathrm{Pd}\left(\mathrm{PPh}_{3}\right)_{4}(0.70 \mathrm{~g}, 0.61 \mathrm{mmol})$ and 2-bromobenzaldehyde $(2.68 \mathrm{~g}, 14.5 \mathrm{mmol})$ in a mixture of dry ethanol $(5 \mathrm{ml})$ and 1,2-dimethoxyethane $(100 \mathrm{ml})$ and the mixture heated at reflux for $48 \mathrm{~h}$. The cooled solution was diluted with diethyl ether $(200 \mathrm{ml})$, extracted with $1 M \mathrm{NaOH}(50 \mathrm{ml})$ and then $1 M \mathrm{HCl}(4 \times 150 \mathrm{ml})$. The acidic phase was made basic $(\mathrm{pH} 14)$ with $6 \mathrm{M} \mathrm{NaOH}$ and extracted with ether $(3 \times 150 \mathrm{ml})$. The dried $\left(\mathrm{MgSO}_{4}\right)$ organic solution yielded the crude product which was purified by flash chromatography on silica, eluting first with chloroform followed by ethyl acetate to yield the product as a pale-yellow oil which solidified on standing $(1.23 \mathrm{~g}$, $85 \%)$, m.p. $348-351 \mathrm{~K} .{ }^{1} \mathrm{H}$ NMR $\left(\mathrm{CDCl}_{3}\right): \delta 9.57(1 \mathrm{H}, s, \mathrm{CHO}), 7.92$ $(1 \mathrm{H}, d, J=7.7), 7.65(1 \mathrm{H}, t, J=7.6), 7.47-7.31(m, 4 \mathrm{H}), 7.14(1 \mathrm{H}, t, J=$ 7.4), $7.06(1 \mathrm{H}, d, J=7.2), 2.38\left[6 \mathrm{H}, s,\left(\mathrm{CH}_{3}\right)_{2} \mathrm{~N}\right] ;{ }^{13} \mathrm{C}$ NMR $\left(\mathrm{CDCl}_{3}\right): \delta$ $190.7(\mathrm{C}=\mathrm{O}), 151.5,142.7,133.8,133.1,131.1(\times 2), 130.0,129.5$, 127.5, 126.7, 123.0, 118.1, $42.2\left[\left(\mathrm{CH}_{3}\right)_{2} \mathrm{~N}\right] ; v_{\max }\left(\mathrm{cm}^{-1}\right)(\mathrm{KBr}): 2832$, 1689, 1594, 1492, 1450, 1247, 1193, 945, 770; HRMS (ES): found: $226.1229(M+\mathrm{H})^{+} ; \mathrm{C}_{15} \mathrm{H}_{15} \mathrm{NO}$ requires: $226.1232(M+\mathrm{H})^{+}$.

2-(N,N-Dimethylamino)biphenyl-2',6'-dicarboxaldehyde, (VII): 2 trimethylstannyl- $N, N$-dimethylaniline $(0.66 \mathrm{~g}, 2.35 \mathrm{mmol})$ and 2 bromoisophthalaldehyde $(0.50 \mathrm{~g}, 2.35 \mathrm{mmol})$ were refluxed in dry tetrahydrofuran (THF) $(25 \mathrm{ml})$ with $\mathrm{Pd}\left(\mathrm{PPh}_{3}\right)_{4}(0.14 \mathrm{~g}, 0.12 \mathrm{mmol})$ and $\mathrm{CuI}(0.03 \mathrm{~g}, 0.17 \mathrm{mmol})$. After $24 \mathrm{~h}$, the amounts of catalysts were doubled and the reaction refluxed for $48 \mathrm{~h}$. The THF was removed on a rotary evaporator, ethyl acetate $(50 \mathrm{ml})$ was added to the residue and the mixture was filtered through Celite. The filtrate was washed 
with water $(3 \times 30 \mathrm{ml})$ and brine $(30 \mathrm{ml})$, dried over $\mathrm{Na}_{2} \mathrm{SO}_{4}$ and evaporated to yield a brown oil. Purification by flash chromatography $\left(\mathrm{SiO}_{2}, 2: 1\right.$ cyclohexane-diethyl ether) yielded (VII) as a yellow oil which solidified on standing (0.10 g, 17\%), m.p. 371-374 K. ${ }^{1} \mathrm{H}$ NMR $\left(\mathrm{CDCl}_{3}\right): \delta 9.75(1 \mathrm{H}, s, \mathrm{CHO}), 9.74(1 \mathrm{H}, s, \mathrm{CHO}), 8.24(2 \mathrm{H}, d, J=7.7)$, $7.62(1 \mathrm{H}, t, J=7.7), 7.45(1 \mathrm{H}, m), 7.15(3 \mathrm{H}, m), 2.45\left[6 \mathrm{H}, s,\left(\mathrm{CH}_{3}\right)_{2} \mathrm{~N}\right]$; ${ }^{13} \mathrm{C}$ NMR $\left(\mathrm{CDCl}_{3}\right): \delta 191.2(\mathrm{C}=\mathrm{O}), 152.4,146.2,133.9,133.7,132.6$, $130.7,128.0,124.9,122.3,118.6,42.5\left[\left(\mathrm{CH}_{3}\right)_{2} \mathrm{~N}\right] ; v_{\max }\left(\mathrm{cm}^{-1}\right)(\mathrm{KBr})$ : 2859, 1681, 1491, 1456, 1386, 1234, 945, 922, 799, 770; HRMS (ES): found: $254.1178(M+\mathrm{H})^{+} ; \mathrm{C}_{16} \mathrm{H}_{15} \mathrm{NO}_{2}$ requires: $254.1181(M+\mathrm{H})^{+}$.

\section{Compound (VI)}

\section{Crystal data \\ $\mathrm{C}_{15} \mathrm{H}_{15} \mathrm{NO}$ \\ $M_{r}=225.28$ \\ Monoclinic, $P 2_{1} / n$ \\ $a=8.169(2) \AA$ \\ $b=11.042(3) \AA$ \\ $c=13.745(4) \AA$ \\ $\beta=101.89(1)^{\circ}$ \\ $V=1213.1(6) \AA^{3}$ \\ $Z=4$}

Data collection

KappaCCD diffractometer $\varphi$ and $\omega$ scans

Absorption correction: multi-scan

(SORTAV; Blessing, 1995)

$T_{\min }=0.906, T_{\max }=0.983$

12528 measured reflections

2783 independent reflections

\section{Refinement}

Refinement on $F^{2}$

$R\left[F^{2}>2 \sigma\left(F^{2}\right)\right]=0.051$

$w R\left(F^{2}\right)=0.126$

$S=1.08$

2783 reflections

214 parameters

All $\mathrm{H}$-atom parameters refined

\section{Compound (VII)}

Crystal data
$\mathrm{C}_{16} \mathrm{H}_{15} \mathrm{NO}_{2}$
$M_{r}=253.29$
Orthorhombic, Pca $2_{1}$
$a=14.161(3) \AA$
$b=27.913(6) \AA$
$c=6.7018(13) \AA$
$V=2648.9(9) \AA^{3}$
$Z=8$
$D_{x}=1.270 \mathrm{Mg} \mathrm{m}^{-3}$

\section{Data collection}

KappaCCD diffractometer $\varphi$ and $\omega$ scans

Absorption correction: multi-scan

(SORTAV; Blessing, 1995)

$T_{\min }=0.873, T_{\max }=0.994$

14314 measured reflections

3238 independent reflections

\section{Refinement}

Refinement on $F^{2}$

$R\left[F^{2}>2 \sigma\left(F^{2}\right)\right]=0.044$

$w R\left(F^{2}\right)=0.100$

$S=0.97$

3238 reflections

463 parameters
$D_{x}=1.233 \mathrm{Mg} \mathrm{m}^{-3}$

Mo $K \alpha$ radiation

Cell parameters from 2931 reflections

$\theta=2.9-27.5^{\circ}$

$\mu=0.08 \mathrm{~mm}^{-1}$

$T=150$ (2) K

Block, yellow

$0.40 \times 0.40 \times 0.25 \mathrm{~mm}$

2211 reflections with $I>2 \sigma(I)$

$R_{\text {int }}=0.043$

$\theta_{\max }=27.5^{\circ}$

$h=-10 \rightarrow 10$

$k=-14 \rightarrow 14$

$l=-15 \rightarrow 17$

$w=1 /\left[\sigma^{2}\left(F_{o}{ }^{2}\right)+(0.0776 P)^{2}\right.$
$\quad+0.0677 P]$
where $P=\left(F_{o}{ }^{2}+2 F_{c}{ }^{2}\right) / 3$
$(\Delta / \sigma)_{\max }=0.008$
$\Delta \rho_{\max }=0.23 \mathrm{e}^{-3}$
$\Delta \rho_{\min }=-0.38 \mathrm{e}^{-3}$

Mo $K \alpha$ radiation

Cell parameters from 4682 reflections

$\theta=2.9-27.5^{\circ}$

$\mu=0.08 \mathrm{~mm}^{-1}$

$T=150(2) \mathrm{K}$

Block, yellow

$0.25 \times 0.20 \times 0.08 \mathrm{~mm}$

2378 reflections with $I>2 \sigma(I)$

$R_{\text {int }}=0.052$

$\theta_{\max }=27.5^{\circ}$

$h=-13 \rightarrow 18$

$k=-28 \rightarrow 36$

$l=-8 \rightarrow 8$

All $\mathrm{H}$-atom parameters refined

$w=1 /\left[\sigma^{2}\left(F_{o}^{2}\right)+(0.0635 P)^{2}\right]$

where $P=\left(F_{o}^{2}+2 F_{c}^{2}\right) / 3$

$(\Delta / \sigma)_{\max }=0.005$

$\Delta \rho_{\max }=0.18$ e $\AA^{-3}$

$\Delta \rho_{\min }=-0.23 \mathrm{e} \AA^{-3}$
Table 1

Selected molecular geometry $\left(\AA,^{\circ}\right)$ for (VI) and (VII).

\begin{tabular}{lccc}
\hline & $(\mathrm{VI})$ & $(\mathrm{VII} A)$ & $(\mathrm{VII} B)$ \\
\hline $\mathrm{N} 1 \cdots \mathrm{C} 15$ & $2.9891(16)$ & $2.929(3)$ & $3.029(3)$ \\
$\mathrm{N} 1 \cdots \mathrm{C} 15-\mathrm{O} 1$ & $126.48(9)$ & $123.8(2)$ & $128.1(2)$ \\
Inter-ring angle & $58.94(6)$ & $58.1(1)$ & $62.4(1)$ \\
$\mathrm{N} 1-\mathrm{C} 2$ & $1.4220(15)$ & $1.402(3)$ & $1.410(3)$ \\
$\Sigma$ bond angles at N1 & $341.8(3)$ & $342.5(2)$ & $341.3(2)$ \\
C14-N1-C2-C3 & $14.89(16)$ & $-13.3(3)$ & $15.0(3)$ \\
$\mathrm{O} 1-\mathrm{C} 15-\mathrm{C} 8-\mathrm{C} 9$ & $6.16(19)$ & $-10.3(4)$ & $-7.7(4)$ \\
\hline
\end{tabular}

All $\mathrm{H}$ atoms were located in difference Fourier maps and refined with individual isotropic displacement parameters. The $\mathrm{C}-\mathrm{H}$ bond lengths are 0.947 (16)-1.033 (15) $\AA$ in (VI) and 0.92 (3)-1.08 (2) $\AA$ in (VII). For compound (VII), reflection data include 1362 merged Friedel pairs (as the absolute structure was not determined).

For both compounds, data collection: DENZO (Otwinowski \& Minor, 1997) and COLLECT (Hooft, 1998); cell refinement: DENZO and COLLECT; data reduction: DENZO and COLLECT; program(s) used to solve structure: SHELXS97 (Sheldrick, 1990); program(s) used to refine structure: SHELXL97 (Sheldrick, 1997); molecular graphics: ORTEPIII (Johnson \& Burnett, 1996).

We thank Professor M. B. Hursthouse and the EPSRC National X-ray Crystallography Service for collecting the data sets.

Supplementary data for this paper are available from the IUCr electronic archives (Reference: GG1051). Services for accessing these data are described at the back of the journal.

\section{References}

Allen, F. H. \& Kennard, O. (1993). Chem. Des. Autom. News, 8, 1, 31-37. Bell, P. C. \& Wallis, J. D. (1999). J. Chem. Soc. Chem. Commun. pp. 257-258. Blessing, R. H. (1995). Acta Cryst. A51, 33-38.

Bürgi, H.-B., Dunitz, J. D. \& Schefter, E. (1973a). J. Am. Chem. Soc. 95, 50655067.

Bürgi, H.-B., Dunitz, J. D. \& Schefter, E. (1973b). Cryst. Struct. Commun. 2, $667-672$.

Bye, E. (1974). Acta Chem. Scand. Ser. B, 28, 5-9.

Byrne, J. J., Chavant, P. Y., Averbuch-Pouchot, M.-T. \& Vallée, Y. (1998). Acta Cryst. C54, 1154-1156.

Clayden, J., McCarthy, C. \& Helliwell, M. (1999). J. Chem. Soc. Chem. Commun. pp. 2059-2060.

Ferreira, M. A., Costa, M. D. D., Mendes, I. M. C., Drumond, M. G., PiloVeloso, D. \& Fernandes, N. G. (1998). Acta Cryst. C54, 837-840.

Hodgson, D. R. W., Kirby, A. J. \& Feeder, N. (1999). J. Chem. Soc. Perkin Trans. 1, pp. 949-954.

Hooft, R. (1998). COLLECT. Nonius BV, Delft, The Netherlands

Johnson, C. K. \& Burnett, M. N. (1996). ORTEPIII. Report ORNL-6895. Oak Ridge National Laboratory, Tennessee, USA.

Jones, J. B. \& Brown, D. S. (1982). Acta Cryst. B38, 317-319.

Krygowski, T. M., Anulewicz, R., Daniluk, T. \& Drapala, T. (1989). Struct. Chem. 1, 371-378.

Lin, W. O., da Costa, J. B. N., Alt, H. G. \& Rogers, R. D. (1989). Z. Naturforsch. Teil B, 44, 1331-1332.

Neronova, N. N. (1968). Zh. Strukt. Khim. 9, 147-148.

O'Leary, J., Bell, P. C., Schweizer, W. B. \& Wallis, J. D. (2001). J. Chem. Soc. Perkin Trans. 2, pp. 133-139.

Ottersen, T. (1977). Acta Chem. Scand. Ser. A 31, 480-484.

Otwinowski, M. \& Minor, W. (1997). Methods Enzymol. 276, 307-326.

Sartori, G., Maggi, R., Bigi, F., Arienti, A., Casnati, G., Bocelli, G. \& Mori, G. (1992). Tetrahedron, 48, 9483-9494.

Schweizer, W. B., Procter, G., Kaftory, M. \& Dunitz, J. D. (1978). Helv. Chim. Acta, 61, 2783-2808.

Sheldrick, G. M. (1990). Acta Cryst. A46, 467-473.

Sheldrick, G. M. (1997). SHELXL97. University of Göttingen, Germany.

Staab, H. A., Krieger, C. \& Hone, M. (1988). Tetrahedron Lett. 29, 5629-5632. 